\title{
ANALISIS PENGARUH KEADILAN KOMPENSASI TERHADAP KEPUASAN KERJA \\ DAN PERBEDAAN PERSEPSI KEADILAN KOMPENSASI DAN KEPUASAN KERJA BERDASARKAN JENIS PEKERJAAN PADA KARYAWAN NISSAN BANTUL YOGYAKARTA
}

\author{
Dedy Surya Yuniantara ${ }^{1}$ \\ ${ }^{1}$ Universitas Muhammadiyah Yogyakarta \\ dedy.soerja@gmail.com
}

\begin{abstract}
With the good and fair of compensation will spur the spirit and creativity of the work so that it can show the performance, which will ultimately increase good productivity. The compensation granted to employees is very influential on the level of job satisfaction and motivation, as well as the work results.

This research is purposed to exam whether compensation fairness effect on employee job satisfaction, and whether there is difference in the perception of compensation fairness and job satisfaction based on the job type. Compensation fairness is using the distributive fairness and procedural fairness constructs (Tjahjono, 2007). This research has been conducted at Nissan Bantul Yogyakarta. A total of 58 employees in marketing and non-marketing division participates provide an answer for this research. To examine the effect of independent sample t-test, the data are analyzed using SPSS.

The analysis shows that there is the effect of compensation distributive fairness on job satisfaction, the effect of procedural compensation fairness on job satisfaction, and no difference in perception between marketing and non-marketing employees.
\end{abstract}

Keywords : Compensation Fairness, Job Satisfaction and job type

(C) 2017 JBTI. All rights reserved

Article history : received 17 Jul 2016; revised 18 Ags 2016; accepted 20 Jan 2017

\section{PENDAHULUAN}

Nissan Yogyakarta merupakan perusahaan distribusi Nissan di Yogyakarta yang berbasis penyediaan fasilitas konsumen yang lengkap, sumber daya manusia yang kompeten, kreatif, inovatif dan berkomitmen tinggi dibidangnya, finance yang kuat dan sistem teknologi yang handal.

Penciptaan produk yang sesuai dengan selera konsumen dan meningkatkan brand image merupakan cara yang efektif dalam memenangkan persaingan. Namun kita tidak bisa memungkiri bahwa strategi marketing yang tepat dan optimal juga merupakan salah satu faktor penting dalam mencapai tujuan tersebut. Nissan Yogyakarta nampaknya sudah menyadari hal ini, sebagai distributor utama Nissan untuk wilayah DIY dan Perusahaan berusaha untuk mengoptimalkan divisi Marketingnya. Jalan yang ditempuh salah satunya adalah memberikan kompensasi terhadap karyawan divisi Marketing yang dibuat berbeda dari karyawan non marketing.

Perbedaan mendasar struktur gaji seorang marketing dengan karyawan non Marketing dimana jika karyawan lain mendapatkan kompensasi berupa gaji pokok, uang makan dan uang transport yang diterima jumlahnya tetap tiap bulan atau bisa disebut kompensasi berdasarkan waktu, 
maka pada divisi marketing ini selain mendapatkan insentif diatas, mereka juga mendapatkan kompensasi penjualan berupa insentif penjualan per unit jika konsumen membeli mobil secara cash, ditambah refund kredit per unit jika konsumen membeli mobil secara kredit atau dengan kata lain kompensasi yang diterima berdasarkan prestasi kerja. Karyawan marketing menerima gaji yang tidak tetap perbulannya bahkan berbeda dari sesama marketing sekalipun, karena besarnya gaji tergantung dari jumlah unit mobil yang berhasil mereka jual, sehingga jika ingin mendapatkan penghasilan yang besar, maka karyawan harus bisa menjual mobil dengan jumlah yang besar pula. Intinya adalah bahwa jumlah nominal gaji yang mereka dapatkan adalah tidak tetap karena sesuai hasil kerja yang telah mereka lakukan. Hal ini menarik peneliti untuk melakukan sebuah studi tentang apakah pemberian kompensasi sistem insentif tersebut sudah dirasa adil bagi karyawan baik marketing maupun non marketing dan mempengaruhi kepuasan kerja mereka.

Setiap orang pasti menghendaki perlakuan yang adil baik dari sisi distribusi dan prosedur atau disebut sebagai keadilan distributif dan keadilan prosedural (Tjahjono, 2007). Karyawan juga mengharapkan adanya keadilan dan keterbukaan pada sistem dan proses pemberian kompensasi (Palupi, 2013). Namun dalam pemberian kompensasi terkadang menimbulkan kecemburuan sosial antara karyawan satu dengan karyawan lainnya, jika pemberian kompensasi tersebut dirasa tidak adil dan baik, maka akan mengakibatkan menurunnya tingkat kepuasan kerja karyawan, hal ini terjadi karena karyawan merasa tidak diberlakukan adil dalam pemberian kompensasi. Kondisi tersebut akan mengakibatkan kepuasan kerja pegawai tidak tercapai dan menjadi tidak produktif dalam bekerja. Hal buruk lain adalah kadang terjadi persaingan yang tidak sehat antar sesama marketing sehingga target yang dibebankan kepada marketing tidak tercapai. Hal ini sangat merugikan bagi perusahaan karena dirasa tidak efektif, efisien, dan optimal.

Penelitian ini akan membahas pengaruh Keadilan Distributif dan Prosedural Kompensasi. Fungsi dari variabel Jenis Pekerjaan disini adalah sebagai variabel pembanding yang mana dari variabel ini akan diketahui terdapat atau tidaknya perbedaan persepsi keadilan kompensasi dan kepuasan kerja dari karyawan marketing dan divisi non marketing.

Berdasarkan latar belakang di atas, permasalahan yang akan dibahas dalam penelitian ini adalah :

a. Apakah keadilan distributif kompensasi berpengaruh terhadap kepuasan kerja karyawan di Nissan Bantul Yogyakarta?"

b. Apakah keadilan prosedural kompensasi berpengaruh terhadap kepuasan kerja karyawan di Nissan Bantul Yogyakarta?"

c. Apakah terjadi perbedaan persepsi keadilan distributif kompensasi antara karyawan divisi marketing dan divisi non marketing di Nissan Bantul Yogyakarta?

d. Apakah terjadi perbedaan persepsi keadilan prosedural kompensasi antara karyawan divisi marketing dan divisi non marketing di Nissan Bantul Yogyakarta?

e. Apakah terjadi perbedaan persepsi kepuasan kerja antara karyawan divisi marketing dan divisi non marketing di Nissan Bantul Yogyakarta?

Berdasarkan pada perumusan masalah, penelitian ini dilakukan dengan tujuan sebagai berikut:

a. Menguji dan menganalisis pengaruh keadilan distributuf kompensasi terhadap kepuasan kerja karyawan di Nissan Bantul Yogyakarta.

b. Menguji dan menganalisis pengaruh keadilan prosedural kompensasi terhadap kepuasan kerja karyawan di Nissan Bantul Yogyakarta.

c. Menguji dan menganalisis perbedaan persepsi keadilan distributuf kompensasi antara karyawan divisi marketing dan divisi non marketing di Nissan Bantul Yogyakarta? 
d. Menguji dan menganalisis perbedaan persepsi keadilan prosedural kompensasi antara karyawan divisi marketing dan divisi non marketing di Nissan Bantul Yogyakarta?

e. Menguji dan menganalisis perbedaan persepsi kepuasan kerja antara karyawan divisi marketing dan divisi non marketing di Nissan Bantul Yogyakarta?

Berdasarkan pada tujuan yang telah dikemukakan penelitian ini diharapkan memberikan manfaat sebagai berikut :

a. Bagi akademisi, hasil penelitian ini diharapkan dapat memberikan kontribusi pada pengembangan teori sumber daya manusai terutama yang berkaitan dengan keadilan organisasi.

b. Bagi para karyawan, dapat membantu untuk mengenali dan peka terhadap masalah-masalah yang berkaitan dengan keadilan kompensasi dan secara spesifik dapat meningkatkan pemahaman atas faktor-faktor yang mempengaruhi sikap individu terhadap kepuasan kerja.

c. Bagi perusahaan, hasil penelitian ini diharapkan dapat memberikan kontribusi praktis bagi organisasi guna kesuksesan perencanaan dan implementasi kepuasan kerja melalui keadilan kompensasi.

\section{KAJIAN TEORI}

\section{A. Keadilan Kompensasi}

Keadilan dalam pemberian kmpensasi adalah suatu keharusan dalam rangka mebjaga hubungan baik antara perusahaan dan karyawan. Keadilan penggajian berperan negatif sebagai penyebab utama perilaku menyimpang (Greenberg 1990 dalam Palupi 2013). Apabila terjadi ketidakadilan maka akan berdampak pada menurunnya daya tarik pekerjaan, yang pada akhirnya akan mengakibatkan meningkatnya perputaran karyawan, ketidakpuasan terhadap pekerjaan maupun absensi (Suhartini, 2005). Mendapatkan kompensasi untuk memenuhi kebutuhan hidup merupakan tujuan utama seseorang bekerja, oleh karena itu layak tidaknya kompensasi yang diterima pegawai sangat mempengaruhi tingkat kepuasan kerjanya. Seseorang yang bekerja akan merasa lebih dihargai oleh masyarakat di sekitarnya, dibandingkan yang tidak bekerja. Mereka akan merasa lebih dihargai lagi apabila menerima berbagai fasilitas dan simbol-simbol status lainnya dari perusahaan mereka bekerja (Muljani, 2002).

Teori tentang keadilan mengindikasikan bahwa ada dua bentuk keadilan:(i) keadilaan distributif, yang memfokuskan pada respon yang berorientasi pada keadilan terhadap hasil akhir dan (ii) keadilan prosedural, yang memfokuskan pada respon yang berorientasi pada keadilan aturan dan prosedur dalam perusahaan. Literatur yang ada mengindikasikan bahwa kecemasan akan prosedur dalam perusahaan mengacu pada penilaian keadilan yang independen terhadap keadilan distributif (Thibaut \& Walker, 1975; Lind dan Tyler, 1988 dalam Latif, 2007).

Dalam konteks kompensasi, keadilan distributif kompensasi merupakan persepsi karyawan mengenai pendistribusian imbalan dalam organisasi yang mencakup pembayaran/kompensasi dalam sebuah organisasi (Tjahjono, 2008). Keadilan distributif berkaitan erat dengan distribusi hasil (Colquitt, 2001 dalam Tjahjono, 2007) dan telah menjadi pertimbangan fundamental dalam teori keadilan selama 40 tahun terakhir. Pembahasan mengenai keadilan distributif berfokus pada keadilan keputusan terhadap hasil-hasil (Adam; Deutsch; Homann; Leventhal dalam Tjahjono, 2007). Hasil yang diterima karyawan tersebut bersifat personal yang dipersepsikan oleh masing-masing individu untuk menilai keadilan distributif. Oleh karena itu, keadilan distributif dibandingkan keadilan prosedural akan berpengaruh positif lebih kuat pada outcomes personal. 
Keadilan distributive dapat dikatakan baik jika karyawan merasa distribusi pemberian kompensasi yang diterimanya dirasa adil dan berimbang.

Sementara dalam konteks prosedural, keadilan kompensasi merupakan persepsi karyawan mengenai mekanisme dan evaluasi alokasi kompensasi dalam organisasi (Tjahjono, 2008). Penilaian keadilan prosedural sebagai komplemen yang dinilai tidak dapat terpisahkan dari penilaian keadilan distributif (Thibaut \& Walker, 1978 dalam Tjahjono, 2007). Konsep keadilan prosedural menjelaskan bahwa individu tidak hanya melakukan evaluasi terhadap alokasi atau distribusi hasil-hasil, namun juga mengevaluasi terhadap keadilan prosedur untuk menentukan alokasi tersebut.

Menurut Greenberg dan Baron (2003) keadilan prosedural didefinisikan sebagai persepsi keadilan atas pembuatan keputusan dalam organisasi. Orang-orang di dalam organisasi sangat memperhatikan dalam pembuatan keputusan secara adil dan mereka merasa bahwa organisasi dan karyawan akan sama-sama merasa diuntungkan jika organisasi melaksanakan prosedur secara adil.

\section{B. Kepuasan Kerja}

Menurut Locke, (1969, dalam Wexley dan Yuki, 2005) mendefinisikan kepuasan sebagai tidak ada selisihnya antara kondisi-kondisi yang diinginkan dengan kondisi-kondisi aktual. Sementara itu kepuasan kerja dapat didefinisikan sebagai suatu perasaan positif tentang pekerjaan seseorang yang merupakan hasil dari sebuah evaluasi karakteristiknya (Robbins dan Judge, 2007). Tingkat kepuasan kerja dapat terukur berdasarkan beberapa indikator yaitu dari pekerjaan itu sendiri, penghasilan. Kepuasan kerja mempunyai banyak dimensi, secara umum tahap yang diamati adalah kepuasan dalam pekerjaan itu sendiri, gaji, pengakuan, hubungan antara supervisor dengan tenaga kerja, dan kesempatan untuk maju. Setiap dimensi menghasilkan perasaan puas secara keseluruhan dengan pekerjaan itu sendiri, namun pekerjaan juga mempunyai definisi yang berbeda bagi orang lain (Mathis \& Jackson, 2001).

Kepuasan kerja bersifat multidimensional maka kepuasan kerja dapat mewakili sikap secara menyeluruh (kepuasan umum) maupun mengacu pada bagian pekerjaan seseorang. Artinya jika secara umum mencerminkan kepuasannya sangat tinggi tetapi dapat saja seseorang akan merasa tidak puas dengan salah satu atau beberapa aspek saja misalnya jadwal liburan (Davis, Keith. 1985 dalam Ruvendi 2005). Konsekuensi dari kepuasan kerja dapat berupa meningkat atau menurunnya prestasi kerja pegawai, pergantian pegawai (turnover), kemangkiran, atau pencurian (Davis dan Keith, 1985 dalam Ruvendi 2005).

\section{Persepsi Karyawan berdasarkan Jenis Pekerjaan}

Secara umum terdapat perbedaan sistem pemberian kompensasi yang mendasar yang dapat dibedakan berdasarkan jenis pekerjaan, yaitu antara karyawan marketing dan non marketing di Nissan Yogyakarta. Perbedaan sistem kompensasi tersebut adalah:

\section{1) Sistem kompensasi pada karyawan Marketing}

Karyawan Marketing memperoleh kompensasi berdasarkan sistem prestasi yaitu mengaitkan secara langsung antara besarnya upah dengan prestasi kerja yang ditujukan oleh karyawan yang bersangkutan. Sedikit banyaknya upah tersebut tergantung pada sedikit banyaknya hasil yang dicapai karyawan dalam waktu tertentu atau bersifat kuantitatif karena disamping mendapat gaji pokok dan tunjangan-tunjangan yang bersifat tetap tiap bulan, karyawan juga mendapatkan insentif yang besarnya tergantung jumlah unit barang yang bisa dia jual ke konsumen. Hal ini membuat take home pay seorang marketing jumlahnya tidak tetap tiap bulannya.

2) Sistem kompensasi pada karyawan non marketing. 
Karyawan marketing mendapatkan kompensasi berdasarkan sistem waktu yaitu Besarnya kompensasi dihitung berdasarkan standar waktu per satu Bulan kerja. Besarnya Upah ditentukan oleh lamanya karyawan melaksanakan atau menyelesaikan suatu pekerjaan karena hanya menerima gaji pokok ditambah tunjangan-tunjangan yang berjumlah tetap tiap bulannya.

Perbedaan sistem kompensasi diatas dapat menyebabkan perbedaan kompensasi yang diterima karyawan marketing dengan kompensasi yang diterima karyawan non marketing yang memungkinkan timbulnya rasa ketidakadilan dalam pemberian kompensasi dan perbedaan tingkat kepuasan kerja pada keduanya. Hal ini dapat menyebabkan terjadinya perbedaan persepsi keadilan kompensasi dan kepuasan kerja antara karyawan marketing dan non marketing di kedua divisi tersebut.

\section{Hipotesis dan hubungan antar variable}

\section{1) Pengaruh Keadilan Distributif Kompensani terhadap Kepuasan Kerja}

Dalam konteks kompensasi, keadilan distributif kompensasi merupakan persepsi karyawan mengenai pendistribusian imbalan dalam organisasi yang mencakup pembayaran/kompensasi dalam sebuah organisasi (Tjahjono, 2008). Keadilan distributif adalah prediktor yang lebih kuat bagi kepuasan kerja dibanding prosedural. Keadilan distributif merupakan prediktor penting bagi personal outcome karyawan, misalnya kepuasan kerja (Tjahjono, 2008). Penelitian yang dilakukan oleh Nadiri dan Tanova (2010), Dundar dan Tabancali (2012) menghasilkan pengaruh yang signifikan dari keadilan distributif terhadap kepuasan kerja. Berdasarkan penelitian diatas dapat ditarik suatu hipotesis :

H1: Ada pengaruh yang positif dan signifikan dari Keadilan Distributif Kompensasi terhadap kepuasan kerja.

\section{2) Pengaruh Keadilan Prosedural Kompensasi terhadap Kepuasan Kerja}

Proses atau prosedur pemberian kompensasi sangat mempengaruhi penilaian seorang karyawan terhadap ketidakadilan. Menurut Greenberg dan Baron (2003) keadilan prosedural didefinisikan sebagai persepsi keadilan atas pembuatan keputusan dalam organisasi. Keadilan proseduraal dalam konteks kompensasi merupakan persepsi karyawan mengenai mekanisme dan evaluasi alokasi kompensasi dalam organisasi (Tjahjono, 2008). Masterson et al.(2010) menyatakan bahwa keadilan prosedural berhubungan dengan kepuasan kerja. Penelitian Tjahjono (2008), Nadiri dan Tanova (2010), Dundar dan Tabancali (2012), dan mengungkapkan bahwa terdapat pengaruh yang signifikan keadilan prosedural kompensasi terhadap kepuasan kerja . Berdasarkan temuantemuan tersebut, maka hipotesis penelitian ini adalah :

H2: Ada pengaruh yang positif dan signifikan dari Keadilan Prosedural Kompensasi terhadap kepuasan kerja.

3) Perbedaan Persepsi keadilan kompensasi dan kepuasan kerja Karyawan berdasarkan Jenis Pekerjaan

Terdapatnya perbedaan prosedur dan distribusi kompensasi karyawan divisi marketing dan non marketing sangat memungkinkan terjadinya persepsi keadilan kompensasi dan kepuasan kerja karyawan yang berbeda dari kedua divisi tersebut. Hal ini sangat dipengaruhi oleh besar jumlah kompensasi yang diterima yang berbeda antara kedua divisi tersebut dimana karyawan non marketing menerima kompensasi yang tetap tiap bulannya sementara karyawan marketing menerima kompensasi yang besarnya berdasarkan gaji pokok yang ditambah dengan bonus 
penjualan yang jumlahnya selalu berubah tiap bulannya sesuai kinerja masing-masing marketing. Berdasarkan uraian di atas, maka dapat diajukan hipotesis penelitian sebagai berikut:

H3: Ada perbedaan persepsi keadilan distributif kompensasi yang signifikan antara karyawan divisi marketing dan non marketing.

H4: Ada perbedaan persepsi keadilan prosedural kompensasi yang signifikan antara karyawan divisi marketing dan non marketing.

H5: Ada perbedaan persepsi kepuasan kerja yang signifikan antara karyawan divisi marketing dan non marketing.

\section{METODE PENELITIAN}

Penelitian ini adalah penelitian populasi, Populasi adalah wilayah generalisasi yang terdiri atas obyek/subyek yang mempunyai kualitas dan karakteristik tertentu yang ditetapkan oleh peneliti untuk dipelajari dan kemudian ditarik kesimpulan. Obyek penelitian ini adalah Nissan Bantul Yogyakarta, distributor Nissan untuk wilayah Yogyakarta dan sekitarnya sedangkan semua pegawai Nissan Bantul dijadikan sebagai subyek penelitian ini.

Dalam penelitian ini populasi yang digunakan adalah karyawan Nissan Bantul Yogyakarta berjumlah 58 orang. Prosedur penentuan sampel dilakukan dengan metode Nonprobabilitas dengan teknik Sampling jenuh ialah teknik pengambilan sampel apabila semua populasi digunakan sebagai sampel dan dikenal juga dengan istilah sensus.

Pendekatan yang dilakukan pada penelitian ini adalah pendekatan kuantitatif, berjenis deskriptif dan assosiatif. Disebut memakai pendekatan kuantitatif sebab pendekatan yang digunakan di dalam penelitian ini nantinya menggunakan aspek pengukuran dan perhitungan. Kemudian disebut penelitian deskriptif karena bertujuan membuat deskripsi mengenai fakta-fakta dan sifatsifat suatu populasi yang akan diteliti. Sedangkan dikatakan sebagai penelitian assosiatif karena penelitian ini menghubungkan dua variabel atau lebih.

Penelitian ini menggunakan data kuantitatif dan jenis data primer yaitu data yang mengacu pada informasi yang diperoleh dari tangan pertama oleh peneliti yang berkaitan dengan variabel minat untuk tujuan spesifik studi (Sekaran, 2006). Data primer dalam penelitian ini adalah data persepsi responden tentang keadilan kompensasi dan kepuasan kerja.

Untuk memperoleh data yang dibutuhkan sebagai penunjang dalam penulisan tesis ini, maka pengumpulan data dilakukan dengan cara metode survei menggunakan kuesioner dimana daftar pertanyaan tentang keadilan distributif kompensasi, keadilan prosedural kompensasi, dan kepuasan kerja pegawai yang diberikan kepada pegawai pada pada Nissan Bantul Yogyakarta.

Analisis yang digunakan untuk pengujian hipotesis dalam penelitian ini adalah analisis regresi berganda dengan mempergunakan alat bantu yang berupa aplikasi komputer SPSS versi 16.

\section{ANALISIS DATA DAN HASIL PENELITIAN}

Nissan Yogyakarta merupakan dealer Nissan untuk wilayah Yogyakarta dimana Agen Tunggal Pemegang Merek mobil Nissan di Indonesia yaitu Indomobil Nissan mempercayakan pemasaran Nissan di Yogyakarta pada PT Wahana Sumberbaru Mobil. Nissan Yogyakarta mempunyai 3 buah dealer yaitu Nissan denggung, Nissan Mlati dan yang terakhir Nissan Bantul yang bertanggung jawab atas penjualan, servis dan jaminan ketersediaan spare part mobil-mobil 
produksi Nissan di Yogyakarta. Nissan Bantul merupakan dealer ke tiga di Yogyakarta setelah Nissan Denggung dan Nissan Mlati dan mulai beroperasi pada tanggal 7 Mei 1015. Nisssan Bantul mempunyai 58 karyawan yang mana terdiri dari 25 karyawan marketing dan 33 orang non marketing.

\section{A. Karakteristik Responden}

Berdasarkan hasil karakteristik responden di Nissan Bantul Yogyakarta diketahui bahwa mayoritas karyawan berjenis kelamin laki-laki dengan terlihat sebanyak 36 orang atau $75.0 \%$ adalah laki-laki dan perempuan sebanyak 12 orang atau $25.0 \%$. Mayoritas karyawan berusia antara $20-30$ tahun yaitu sebanyak 44 orang atau 91.7\%, artinya karyawan Nissan Bantul Yogyakarta kebanyakan masih berusia produktif yang dapat dikatakan kebanyakan karyawan telah menguasai bidang kerja yang digelutinya. Kemudian kebanyakan karyawan berpendidikan terakhir pada tingkat SMA/Sederajat yaitu sebanyak 27 orang atau 56.2\%, berturut-turut karyawan dengan tingkat pendidikan D3 ada 1 orang atau 2.1\% dan tingkat pendidikan terakhir Strata 1 (S1) ada 20 orang atau $41.7 \%$, juga mayoritas telah bekerja selama antara $0-3$ tahun yaitu sebanyak 37 orang atau $77.1 \%$, berturut-turut karyawan dengan masa kerja $4-6$ tahun ada 9 orang atau $18.8 \%$ dan lebih dari 10 tahun ada 2 orang atau $4.2 \%$. yang terakhiir adalah jenis pekerjaan dimana sebanyak 25 orang atau $52.1 \%$ adalah karyawan marketing dan non marketing sebanyak 23 orang atau $47.9 \%$.

\section{Uji Validitas}

Uji validitas akan ditentukan dengan cara mengkorelasikan masing-masing skor item dengan skor total (Korelasi Pearson Product Moment). Pengujian menggunakan uji dua sisi dengan taraf signifikansi 0,05. Output dari hasil pengujian tersebut adalah nilai $\mathrm{r}$ hasil dan nilai signifikansi untuk masing-masing butir kuesioner. Pada pengujian ini, pengambilan keputusan berdasarkan pada $r$ hasil. Jika $r$ hasil positif atau memiliki nilai signifikansi $<0,05(\alpha=5 \%)$, maka butir tersebut dinyatakan valid. Sebaliknya jika $r$ hasil negatif dan $<r$ tabel atau memiliki nilai signifikansi $>0,05$ $(\alpha=5 \%)$, maka butir tersebut dinyatakan tidak valid, $r$ tabel pada pengujian validitas ini adalah 0,179 .

Tabel 1.

Hasil Uji Validitas

\begin{tabular}{|r|l|l|l|l|}
\hline No. & Indikator & $\begin{array}{l}\text { hitung } \\
\text { hig }\end{array}$ & Keterangan \\
\hline 1. & KDK 1 & 0.715 & 0.000 & Valid \\
\hline 2. & KDK 2 & 0.854 & 0.000 & Valid \\
\hline 3. & KDK 3 & 0.616 & 0.000 & Valid \\
\hline 4. & KDK 4 & 0.805 & 0.000 & Valid \\
\hline 5. & KPK 1 & 0.607 & 0.000 & Valid \\
\hline 6. & KPK 2 & 0.802 & 0.000 & Valid \\
\hline 7. & KPK 3 & 0.713 & 0.000 & Valid \\
\hline 8. & KPK 4 & 0.668 & 0.000 & Valid \\
\hline 9. & KPK 5 & 0.738 & 0.000 & Valid \\
\hline
\end{tabular}




\begin{tabular}{|r|l|l|l|l|}
\hline 10. & KPK 6 & 0.695 & 0.000 & Valid \\
\hline 11. & KPK 7 & 0.650 & 0.000 & Valid \\
\hline 12. & KK 1 & 0.649 & 0.000 & Valid \\
\hline 13. & KK 2 & 0.626 & 0.000 & Valid \\
\hline 14. & KK 3 & 0.511 & 0.000 & Valid \\
\hline 15. & KK 4 & 0.700 & 0.000 & Valid \\
\hline 16. & KK 5 & 0.755 & 0.000 & Valid \\
\hline 17. & KK 6 & 0.795 & 0.000 & Valid \\
\hline 18. & KK 7 & 0.684 & 0.000 & Valid \\
\hline
\end{tabular}

Sumber : Data diolah, 2015

Dari Tabel 1 terlihat bahwa semua $r$ hasil bernilai positif dan semua nilai signifikansi $<0,05$ $(\alpha=5 \%)$. Dengan demikian seluruh indikator adalah valid dan siap diteliti lebih lanjut.

\section{Uji Reliabilitas}

Reliabilitas adalah indeks yang menunjukkan seberapa besar suatu alat pengukur dapat dipercaya atau dapat diandalkan. Bila suatu alat pengukur dipakai berulang-ulang untuk mengukur gejala yang sama dan hasil yang diperoleh relatif konsisten, maka alat pengukur tersebut reliable. Pengujian reliabilitas pada penelitian ini menggunakan metode Cronbach's Alpha, karena metode tersebut sangat cocok digunakan pada skor berbentuk skala atau skor rentang. Nilai batasan yang digunakan adalah 0,7 (Sekaran, 2006).

Tabel 2.

Hasil Uji Reliabilitas

\begin{tabular}{|l|l|l|}
\hline Variabel & $\begin{array}{l}\text { Cronbach' } \\
\text { s Alpha }\end{array}$ & $\begin{array}{l}\text { Keteranga } \\
\mathbf{n}\end{array}$ \\
\hline $\begin{array}{l}\text { Keadilan Distributif } \\
\text { Kompensasi (KDK) }\end{array}$ & 0,799 & Reliabel \\
\hline $\begin{array}{l}\text { Keadilan Prosedural } \\
\text { Kompensasi (KPK) }\end{array}$ & 0,772 & Reliabel \\
\hline $\begin{array}{l}\text { Kepuasan Kerja } \\
(\text { KK) }\end{array}$ & 0,765 & Reliabel \\
\hline
\end{tabular}

Sumber : Data diolah, 2015

Berdasarkan tabel 2. di atas maka semua variabel dalam penelitian ini telah reliabel, karena nilai cronbach's alpha $>0,7$. Dengan demikian dapat disimpulkan bahwa semua variabel telah memenuhi persyaratan untuk diteliti lebih lanjut.

3. Uji Multikolinieritas 
Uji multikolinearitas bertujuan untuk menguji apakah model regresi ditemukan adanya korelasi antar variabel bebas (independen). Model regresi yang baik seharusnya tidak terjadi korelasi diantara variabel (Ghozali, 2011).

Untuk dapat menentukan apakah terdapat multikolinearitas dalam model regresi pada penelitian ini adalah dengan melihat nilai VIF (Variance Inflation Factor) dan tolerance

Tabel 3.

Pengujian Multikolinieritas

\begin{tabular}{|l|l|l|}
\hline Variabel & Tolerance & VIF \\
\hline JUMLAH_KDK & .627 & 1.594 \\
\hline JUMLAH_KPK & .627 & 1.594 \\
\hline
\end{tabular}

Sumber : Data Primer yang diolah, 2015

Tabel 3. terlihat bahwa tidak ada variabel yang memiliki nilai VIF lebih besar dari 10 dan nilai tolerance yang lebih kecil dari 10\%, yang berarti bahwa tidak terdapat korelasi antar variabel bebas yang lebih besar dari 95\%. Sehingga dari hal-hal tersebut di atas dapat disimpulkan bahwa tidak terdapat multikolinearitas antar variabel bebas dalam model regresi.

4. Uji Normalitas

Pengujian normalitas dilakukan dengan menggunakan pengujian grafik P-P Plot untuk pengujian residual model regresi seperti ditunjukkan pada Gambar 1:

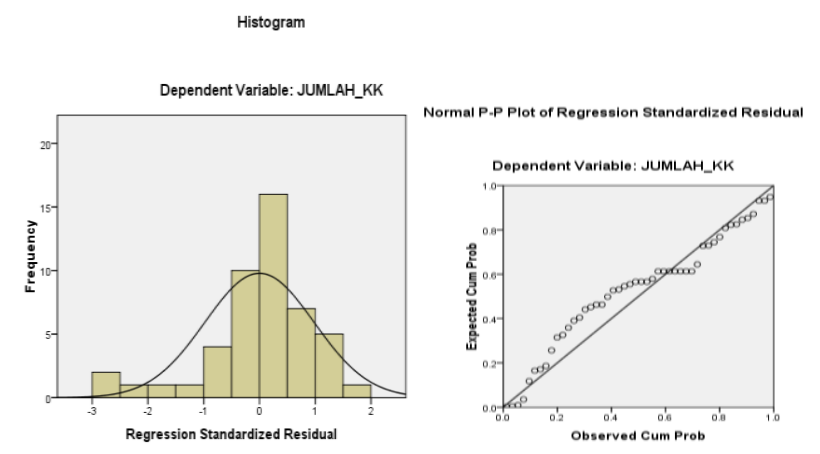

Sumber : Data Primer yang diolah, 2015

Gambar 1. Uji Normalitas Sumber

Berdasarkan Gambar 1 diketahui bahwa sebaran data yang menyebar ke semua daerah kurva normal, berbentuk simetris atau lonceng. Grafik normal probability plot menunjukkan bahwa data menyebar di sekitar garis diagonal dan mengikuti arah garis diagonal. Kemudian untuk lebih meyakinkan bahwa data berdistribusi normal, maka akan dilakukan pengujian secara statistik dengan menggunakan uji Kolomogorov-smirnov. Pengujian terhadap normalitas data dengan menggunakan uji Kolmogorov Smirnov menunjukkan nilai signifikansinya di atas 5\%. Untuk lebih jelasnya dapat dilihat pada Tabel 4: 
Tabel 4.

Uji Kolmogorov-Smirnov

\begin{tabular}{|l|l|}
\hline & $\begin{array}{l}\text { Unstandardized } \\
\text { Residual }\end{array}$ \\
\hline Kolmogorov-Smirnov Z & 1.025 \\
Asymp. Sig. (2-tailed) & .244 \\
\hline
\end{tabular}

Sumber : Data Primer yang diolah, 2015

Sampel hasil pada tabel 4 tersebut menunjukkan rasio Kolmogorov-Smirnov lebih besar dari 0,05. Dari hasil kedua pengujian normalitas baik melalui grafik maupun statistik maka dapat disimpulkan bahwa model regresi memenuhi asumsi normalitas.

\section{Uji Heteroskedastisitas}

Uji heteroskedastisitas bertujuan untuk menguji apakah dalam model regresi terjadi ketidaksamaan varian dari satu pengamatan ke pengamatan yang lain (Ghozali,2011). Cara mendeteksinya adalah dengan melihat ada tidaknya pola tertentu pada grafik Scatterplot antara SRESID dan ZPRED, dimana sumbu $\mathrm{Y}$ adalah $\mathrm{Y}$ yang telah diprediksi, dan sumbu $\mathrm{X}$ adalah residual (Y prediksi - Y sesungguhnya) yang telah di-standardiized (Ghozali,2001). Uji heteroskedastisitas menghasilkan grafik pola penyebaran titik (scatterplot) seperti tampak pada Gambar 2.

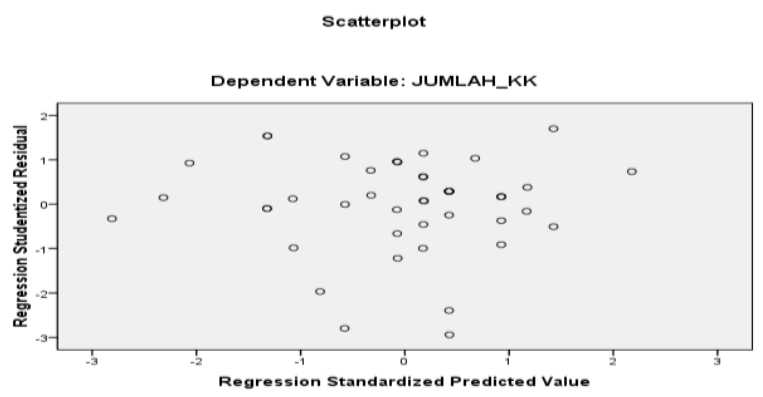

Sumber : Data primer yang diolah, 2015

Gambar 2. Uji Heteroskedastisitas

Hasil pengujian heteroskedastisitas menunjukkan bahwa titik-titik tidak membentuk pola tertentu atau tidak ada pola yang jelas serta titik-titik menyebar di atas dan dibawah angka 0 (nol) pada sumbu Y, maka tidak terjadi heteroskedastisitas.

Dengan demikian asumsi-asumsi normalitas, multikolinearitas dan heteroskesdastisitas dalam model regresi dapat dipenuhi oleh model ini

\section{B. Analisis Regresi Linier Berganda}

Analisis regresi linear berganda digunakan dalam penelitian ini dengan tujuan untuk mengetahui ada tidaknya pengaruh variabel bebas terhadap variabel terikat. Perhitungan 106omputer106 dalam analisis regresi linear berganda yang digunakan dalam penelitian ini adalah 
dengan menggunakan bantuan program komputer SPSS for Windows versi 16.0. Ringkasan hasil pengolahan data dengan menggunakan program SPSS tersebut adalah sebagai berikut :

Tabel 5.

Ringkasan Hasil Regresi

\begin{tabular}{|c|c|c|c|}
\hline Model & $\begin{array}{l}\quad \text { Standardi } \\
\text { zed } \\
\text { Coefficients }\end{array}$ & $\mathbf{t}$ & Sig. \\
\hline & Beta & & \\
\hline $\begin{array}{l}\text { JUMLAH_K } \\
\text { DK }\end{array}$ & .296 & $\begin{array}{ll} & 2.60 \\
7 & \end{array}$ & .012 \\
\hline $\mathrm{PK}^{\text {JUMLAH_K }}$ & .582 & $6^{5.13}$ & .000 \\
\hline
\end{tabular}

Sumber: Data primer yang diolah, 2015

Dari hasil tersebut apabila ditulis dalam bentuk standardized dari persamaan regresinya adalah sebagai berikut :

$$
\mathrm{Y}=0,296 \mathrm{X} 1+0,582 \mathrm{X} 2+\mathrm{e}
$$

Keterangan :

$\mathrm{Y}=$ Kepuasan Kerja (KK)

$\mathrm{X} 1=$ Variabel keadilan distributif kompensasi (KDK)

$\mathrm{X} 2$ = Variabel keadilan prosedural kompensasi (KPK)

$\mathrm{X} 3=$ error

Berdasarkan persamaan regresi di atas bisa terlihat nilai koefisien regresi keadilan distributif kompensasi $(\beta 1)$ bernilai positif sebesar 0,296. Koefisien yang bernilai positif dapat diartikan bahwa apabila keadilan distributif kompensasi mengalami peningkatan, maka kepuasan kerja karyawan juga akan mengalami peningkatan

Kemudian berdasarkan persamaan regresi di atas juga bisa terlihat nilai keadilan prosedural kompensasi $(\beta 2)$ bernilai positif sebesar 0,582 sekaligus sebagai variabel dominan. Koefisien yang bernilai positif dapat diartikan bahwa apabila keadilan prosedural kompensasi mengalami peningkatan, maka kepuasan kerja karyawan juga akan mengalami peningkatan.

\section{Uji t (T test)}

Uji t dimaksudkan untuk mengetahui seberapa jauh pengaruh satu variable independen (keadilan distributif kompensasi dan keadilan prosedural kompensasi) secara individual dalam menerangkan variabel dependen (kepuasan kerja). Hasil uji t pada penelitian ini dapat dilihat pada tabel 5 .

Variabel keadilan distributif kompensasi (KDK)

Ho : b1 = 0 : Keadilan distributif kompensasi (KDK) tidak berpengaruh positif signifikan terhadap kepuasan kerja. 
Ha : b1>0 : Keadilan distributif kompensasi (KDK) berpengaruh positif signifikan terhadap kepuasan kerja.

Hasil pengujian dengan SPSS diperoleh untuk variabel X1 (KDK) diperoleh nilai t hitung = 2,607 dengan tingkat signifikansi 0,012. Dengan menggunakan batas signifikansi 0,05, nilai signifikansi tersebut lebih kecil dari taraf 5\%, yang berarti Ho ditolak dan Ha diterima. Dengan demikian, maka Hipotesis pertama diterima.

Variabel keadilan prosedural kompensasi (KPK)

Ho : b1 = 0 : Keadilan prosedural kompensasi (KPK) tidak berpengaruh positif signifikan terhadap kepuasan kerja.

Ha : b1> 0 : Keadilan prosedural kompensasi (KPK) berpengaruh positif signifikan terhadap kepuasan kerja.

Hasil pengujian dengan SPSS diperoleh untuk variabel X2 (KPK) diperoleh nilai t hitung = 5,136 dengan tingkat signifikansi 0,000. Dengan menggunakan batas signifikansi 0,05, nilai signifikansi tersebut lebih kecil dari taraf 5\%, yang berarti Ho ditolak dan Ha diterima. Dengan demikian, maka Hipotesis kedua diterima.

Dari hasil regresi linear berganda dan uji t pada tabel 4. menunjukkan bahwa kedua koefisien regresi tersebut bertanda positif dan signifikan. Dari model regresi tersebut dapat dijelaskan lebih lanjut yakni sebagai berikut:

a. Variabel Keadilan distributif kompensasi (X1) memiliki pengaruh positif dan signifikan terhadap Kepuasan kerja (Y) dengan nilai regresi 0,296 dan nilai $t$ hitung $=2,607$ dengan tingkat signifikansi 0,012 .

b. Variabel Keadilan prosedural kompensasi (X2) memiliki pengaruh positif dan signifikan terhadap Kepuasan kerja (Y) dengan nilai regresi 0,582 da nilai t hitung = 5,136 dengan tingkat signifikansi 0,000 .

\section{Koefisien Determinasi $\left(\mathrm{R}^{2}\right)$}

Koefisien determinasi $\left(\mathrm{R}^{2}\right)$ pada intinya mengukur seberapa jauh kemampuan model dalam menerangkan variasi variabel dependen. Nilai koefisien determinasi adalah antara nol dan satu (Ghozali, 2011). Nilai koefisien determinasi dapat dilihat pada tabel 5 dibawah ini:

Tabel 6.

Koefisien Determinasi $\left(\mathrm{R}^{2}\right)$

\begin{tabular}{|c|l|l|l|}
\hline Model & $\mathbf{R}$ & $\begin{array}{l}\mathbf{R} \\
\text { Square }\end{array}$ & $\begin{array}{c}\text { Adjusted } \\
\text { Square }\end{array}$ \\
\hline 1 & $.798^{\mathrm{a}}$ & .637 & .621 \\
\hline
\end{tabular}

Sumber : Data primer yang diolah, 2015

Hasil perhitungan dengan menggunakan program SPSS versi 16 dapat diketahui bahwa koefisien determinasi (adjusted R2) yang diperoleh sebesar 0,621. Hal ini berarti 62,1\% variasi kepuasan kerja dapat dijelaskan oleh variabel keadilan distributif kompensasi dan keadilan 
prosedural kompensasi, sedangkan sisanya yaitu 37,9\% variasi kepuasan kerja dipengaruhi oleh variabel-variabel lainnya yang tidak diteliti dalam penelitian ini.

\section{Uji Independent T-Test (Uji Beda)}

Karena data dalam uji coba ini berdistribusi normal, maka uji beda yang digunakan adalah uji beda t-test. Uji beda t-test digunakan untuk menentukan apakah dua sample yang tidak berhubungan memiliki nilai rata-rata yang berbeda (Ghozali, 2011). Apakah nilai kedua grup tersebut mempunyai nilai rata-rata yang sama ataukah tidak sama secara signifikan.

Tabel 7.

Independent T-test Output I

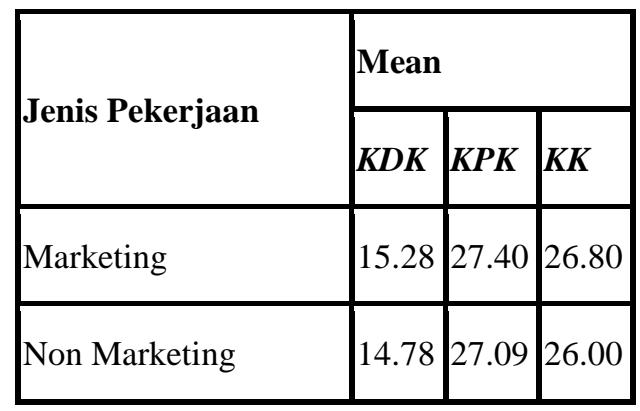

Sumber : Data primer yang diolah, 2015

Pada out put bagian pertama terlihat bahwa semua rata-rata pegawai dengan jenis pekerjaan untuk responden marketing dan kelompok responden non marketing adalah berbeda. Secara absolut jelas bahwa rata-rata pegawai dengan jenis pekerjaan berbeda antara marketing dan non marketing, untuk melihat apakah perbedaan ini memang nyata secara statistic maka harus melihat output bagian kedua (independent sample test).

Tabel 8.

Independent T-test Output II

\begin{tabular}{|c|l|l|l|l|}
\hline & \multicolumn{2}{|l|}{$\begin{array}{l}\text { Levene's Test } \\
\text { for Equality } \\
\text { of Variances }\end{array}$} & $\begin{array}{l}\text { t-test for } \\
\text { Equality of } \\
\text { Means }\end{array}$ \\
\cline { 2 - 5 } & $\boldsymbol{F}$ & Sig. & $\boldsymbol{T}$ & $\begin{array}{l}\text { Sig. } \\
(\mathbf{2 -} \\
\text { tailed })\end{array}$ \\
\hline $\begin{array}{l}\text { Equal } \\
\text { variances } \\
\text { assumed } \\
\begin{array}{l}\text { Equal } \\
\text { Equal } \\
\text { variances not } \\
\text { assumed } \\
\text { distributif }\end{array}\end{array}$ & .907 & .346 & 1.151 & .256 \\
\hline
\end{tabular}




\begin{tabular}{|cl|l|l|l|l|}
\hline & $\begin{array}{l}\text { Equal } \\
\text { variances } \\
\text { assumed }\end{array}$ & 1.366 & .248 & .368 & .714 \\
prosedural & & & & & \\
& $\begin{array}{l}\text { Equal } \\
\text { variances not } \\
\text { assumed }\end{array}$ & & .364 & .718 \\
& $\begin{array}{l}\text { Equal } \\
\text { variances } \\
\text { assumed } \\
\text { Kepuasan } \\
\text { kerja }\end{array}$ & .239 & .627 & .899 & .373 \\
& $\begin{array}{l}\text { Equal } \\
\text { variances not } \\
\text { assumed }\end{array}$ & & .894 & .376 \\
\hline
\end{tabular}

Sumber : data primer yang diolah, 2015

Pada out put bagian kedua ini ada dua tahapan analisis yang harus dilakukan, pertama menguji asumsi terlebih dahulu apakah variance populasi kedua sampel tersebut sama (equal variances assumed) ataukah berbeda (equal variances not assumed) dengan melihat nilai Levene's Test. Kemudian langkah kedua yaitu melihat nilai t-test untuk menentukan apakah terdapat perbedaan nilai rata-rata secara signifikan. Adapun hipotesis untuk mengetahui apakah varian populasi identik ataukah tidak sebagai berikut:

$\mathrm{H}_{0}: \beta_{1}=0$ (kedua kelompok sampel mempunyai varians yang sama)

$\mathrm{H}_{1}: \beta_{1} \neq 0$ (kedua kelompok sampel mempunyai varians yang berbeda)

Pengambilan Keputusan

Jika probabilitas > 0.05, maka H0 tidak dapat ditolak jadi ada persamaan persepsi

Jika probabilitas < 0.05, maka H0 ditolak jadi ada perbedaan persepsi

Terlihat dari tabel 4.18 bahwa semua variabel memiliki nilai probabilitas > 0.05 maka dapat disimpulkan bahwa H0 tidak dapat ditolak atau memiliki varians sama. Dengan demikian analisis uji beda t-test harus menggunakan asumsi equal variance assumed.

Dari tabel 8 terlihat bahwa pada ketiga variabel mempunyai nilai probabilitas signifikansi > 0.05. Jadi dapat disimpulkan bahwa tidak ada perbedaan persepsi keadilan kompensasi dan kepuasan kerja antara karyawan marketing dan non marketing di perusahaan Nissan Yogyakarta.

Tabel 9

Type Styles

\begin{tabular}{|l|l|c|c|}
\hline \multirow{2}{*}{ Table } & \multicolumn{3}{|c|}{ Table Column Head } \\
\cline { 2 - 4 } Head & Table column subhead & $\begin{array}{c}\text { Subhea } \\
d\end{array}$ & $\begin{array}{c}\text { Subhea } \\
d\end{array}$ \\
\hline copy & More table copy $^{\mathrm{a}}$ & & \\
\hline
\end{tabular}

a. Sample of a Table footnote. (Table footnote) 


\section{KESIMPULAN}

Penelitian ini dilakukan untuk menguji mengenai Analisis Pengaruh Keadilan Kompensasi terhadap Kepuasan Kerja dan Perbedaan Persepsi Kepuasan Kerja berdasarkan Jenis Pekerjaan pada Karyawan Nissan Bantul Yogyakarta. Berdasarkan analisis dan pembahasan sebelumnya maka dapat ditarik simpulan sebagai berikut:

a. Hasil uji hipotesis pertama menunjukkan pengaruh yang positif dan signifikan keadilan distributif kompensasi terhadap kepuasan kerja. Hal ini berarti bahwa semakin tinggi keadilan distributif kompensasi maka kepuasan kerja mereka akan meningkat.

b. Hasil uji hipotesis kedua menunjukkan pengaruh yang positif dan signifikan keadilan prosedural kompensasi terhadap kepuasan kerja. Hal ini berarti bahwa semakin tinggi keadilan prosedural kompensasi maka kepuasan kerja mereka akan semakin meningkat.

c. Hasil uji hipotesis menunjukkan tidak adanya perbedaan persepsi keadilan kompensasi dan persepsi kepuasan kerja antara karyawan marketing dan non marketing. Hal ini berarti bahwa antara karyawan pada divisi marketing dan divisi non marketing tidak memiliki perbedaan persepsi keadilan kompensasi dan kepuasan kerja karyawan di Nissan Bantul.

\section{A. Implikasi Manajerial}

Secara teoritis, temuan ini memberikan pemahaman pentingnya situasi tertentu dalam menjelaskan pengaruh keadilan distributif dan prosedural baik terkait dengan kompensasi. Hal tersebut memberikan pemahaman bahwa teori tersebut tidak bersifat universal lintas populasi.

Berdasarkan studi keadilan organisasi merupakan prediktor kuat dalam menjelaskan kepuasan kerja. Upaya peningkatan keadilan organisasi bagi karyawan penting dilakukan dalam rangka meningkatkan kepuasan kerja. Berkaitan dengan dunia praktek, manajemen seharusnya lebih hati-hati dalam mengambil keputusan yang bersifat strategis bagi para karyawannya. Keputusan tersebut akan mempengaruhi perilaku para karyawan di dalam organisasi tersebut apabila dinilai strategis bagi kepentingan mereka.

Persepsi keadilan kompensasi dan kepuasan kerja karyawan seharusnya menjadi perhatian manajemen dalam mengambil kebijakan-kebijakan terhadap karyawan tersebut. Ketika karyawan mempunyai persepsi keadilan kompensasi dan kepuasan kerja dengan pandangan yang baik maka dengan sendirinya akan mempengaruhi perilakunya kearah positif yang selanjutnya diharapkan dapat meningkatkan kinerja karyawan.

\section{B. Keterbatasan Penelitian}

Penelitian ini memiliki beberapa keterbatasan yang perlu diperhatikan. Keterbatasan yang dimiliki penelitian ini, yaitu:

1. Peneliti tidak dapat memberikan kuesioner secara langsung kepada responden dan mendampingi responden dalam mengisi kuesioner. Hal ini disebabkan oleh kesibukan responden dan kendala jenis pekerjaan karyawan yang tidak selalu berada di kantor terutama karyawan pada divisi marketing. Semua responden tidak dapat menyanggupi untuk menjawab kuesioner secara langsung dan meminta waktu hingga satu minggu. Kendala ini menyebabkan tidak dapat diketahui apakah responden benar-benar mengisi kuesioner dengan baik. Juga, peneliti tidak dapat secara langsung menjawab hal-hal yang tidak diketahui oleh responden terkait pertanyaan yang ditanyakan dalam kuesioner. 
2. Pada penelitian ini tidak dilakukan pilot testing untuk memastikan bahwa kuesioner benar-benar dapat dimengerti oleh responden. Namun pengukuran relevansi isi maupun cakupan isi secara kualitatif berdasarkan pertimbangan pakar sudah dilakukan.

3. Penelitian ini hanya menerapkan metode survei melalui kuesioner, sehingga kesimpulan yang diambil hanya berdasarkan pada data yang dikumpulkan melalui penggunaan instrumen secara tertulis.

4. Alat analisis tidak spesifik memberikan rekomendasi karena lebih mengandalkan data-data statistik sehingga mereduksi data-data kualitatif yang sebenarnya dapat memperkaya penjelasan sebuah persoalan.

C. Saran

Dengan adanya keterbatasan dalam penelitian ini, penelitian selanjutnya disarankan dapat memberikan kuesioner langsung kepada responden dan mendampingi mereka dalam mengisi kuesioner. Hal ini diharapkan dapat memperbaiki kualitas dari jawaban responden dan mempersingkat waktu.

Pada penelitian selanjutnya juga disarankan untuk melakukan pilot testing agar kuesioner benar-benar dapat dipahami oleh responden. Pilot testing dapat dilakukan dengan cara mengujicoba dan mendiskusikan kuesioner dengan kerabat yang memiliki karakteristik sama dengan responden.

Perlunya penelitian lanjutan dengan menggunakan model penelitian yang berbeda sehingga diperoleh gambaran akurasi dari penelitian ini, sebagai pembanding sekaligus sebagai generalisasi.

\section{DAFTAR PUSTAKA}

Dundar, T. \& Tabancali, E., 2012, The Relationship Between Organizational Justice Perceptions \& Job Satisfaction Levels. Procedia - Social and Behavioral Sciences, No.46, pp. 5777 5781.

Faturochman., 1999, KeadilanSosial: SuatuTinjauanPsikologi. BuletinPsikologi, Tahun VII, No.l, Juni 1999,13-27.

Faturochman dan Djamaludin Ancok. 2001. Dinamika Psikologis Penilaian Keadilan. Jurnal Psikologi. 1. 41-60.

Ghozali, I., 2011, AplikasiAnalisis Multivariate dengan Program SPSS, Badan Penerbit Universitas Diponegoro, Semarang.

Greenberg, J. dan Baron, RA., 2003, Behavior in organizations. Eighth Edition, New Delhi: Prentice Hall.

Jogiyanto, 2004, Metode Penelitian Bisnis: Salah Kaprah dan Pengalaman-Pengalaman.BPFE: Yogyakarta.

Lambert, E. G., Hogan, N. L., \& Griffin, M. L., 2007, The impact Of Distributive \& Procedural Justice On Correctional Staff Job Stress, Job Satisfaction, \& Organizational Commitment. Journal of Criminal Justice, No. 35, p. $644-656$.

Latif, A.B., 2007, "Hubungan antara Keadilan Prosedural dan Kinerja Manajerial dengan Partisipasi Anggaran sebagai Variabel Intervening (Penelitian terhadap Manajer Perusahaan Manufaktur di Jawa Tengah)”. Tesis, Semarang: Universitas Diponegoro. 
Masterson, S.S., Lewis, K., Goldman, B.M., \& Taylor, M.S., 2000, Integrating Justice \& Social Exchange : The Differing Effects Of Fair Procedures \& Treatment On Work Relationships. Academy Of Management Journal, Vol. 43, No. 4, pp. 738 - 748.

McAuliffe, E., Manafa, O., Maseko, F., Bowie, C., \& White, E., 2009, Understanding Job Satisfaction Amongst Mid-Level Cadres In Malawi: The Contribution Of Organisational Justice. Reproductive Health Matters, Vol. 17, No. 33, pp. 80 - 90.

McFarlin, D.B. \& Sweeney, P.D., 1992, Distributive \& Procedural Justice As Predictors Of Satisfaction With Personal \& Organizational Outcomes. Academy Of Management Journal, Vol. 35, No. 3, pp. $626-637$.

Muljani, N., 2002, Kompensasi Sebagai Motivator Untuk Meningkatkan Kinerja Karyawan. Jurnal Manajemen \& Kewirausahaan Vol.4 No.2, September 2002.

Nadiri, H. \& Tanova, C., 2010, An Investigation Of The Role Of Justice In Turnover Intentions, Job satisfaction, \& Organizational Citizenship Behavior In Hospitality Industry. International Journal of Hospitality Management, No. 29, pp. 33 - 41.

Palupi, M., 2013, Pengaruh Keadilan Kompensasi, Kebijakan Rotasi, dan Komitmen Afektif pada Perilaku Retaliasi PNS Kantor "X" di Yogyakarta. Jurnal Riset Manajemen dan Bisnis, volume 8, No. 1, th. 2013, hal 15-24.

Ruvendi, R., 2005, Imbalan dan Gaya Kepemimpinan Pengaruhnya terhadap Kepuasan Kerja Karyawan di Balai Besar Industri Hasil Pertanian Bogor. Jurnal llmiah Binaniaga, volume 01. No.01 tahun 2005.

Robbins, S.P, and Timothy A.J., 2007, Organizational Behavior. New Jersey: PEARSON Prentice Hall.

Sekaran, U., 2006, Research Methods for Business: Metode Penelitian untuk Bisnis, Penerbit Salemba Empat, Jakarta.

Suhartini, 2005, Keadilan Dalam Pemberian Kompensasi. Jurnal Siasat Bisnis. Edisi Khusus JSB On Human Resources. 2005.

Sutisna, I.W.W. dan Rahyuda, A.G. Pengaruh Keadilan Distribjutif, Prosedural, dan Interaksional terhadap Kepuasan Kerja dan Komitmen Organisi pada Paramedis di Rumah Sakit Tk II Udayana Denpasar. Fakultas Ekonomi dan Bisnis Universitas Udayana (Unud), Bali, Indonesia

Tjahjono, H.K., 2005, Validasi Item-Item Keadilan Distributif dan Keadilan Prosedural : Aplikasi Structural Equation Modeling dengan Confirmatory Factor Analysis (CFA). Jurnal Akuntansi dan Manajemen, No.26/DIKTI/Kep/2005.

Tjahjono, H.K. 2008, Justice in Salary Structure: The Justice Influence Toward Employees Satisfaction. Jurnal Ekonomi dan Bisnis, Ekobis, Vol. 9, No.1, Januari 2008.

Tjahjono, H.K. 2006, Relationship Between Organizational Justice in Performance Appraisal Context and Outcomes; Study on Islamic University in Yogyakarta. Prooceedinglnternational Joint Seminar. 151-164.

Tjahjono, H.K. 2007, Pengaruh Keadilan Organisasional pada Perilaku Kewargaan Organisasional di Tempat Kerja. Jurnal Ekonomi dan Bisnis. 19(2).85-93.

Tjahjono, H.K. 2008, Studi Literatur Pengaruh Keadilan Distributif dan Keadilan Prosedural Pada Konsekuensinya Dengan Teknik Meta Analisis. Jurnal Psikologi Fakultas Psikologi Universitas Gadjah Mada. Volume 35. No.1, 21-40. 
Tjahjono, H.K. 2010. "The Extension of two-factor Model of Justice: Hierarchical Regression Test and Sample Split". China-USA Business Review. 9(7):39-54

Tjahjono, H.K. 2015. Metode Penelitian Bisnis. VSM MM UMY

Tjahjono, H.K. 2015. Manajemen Sumberdaya Manusia. VSM MM UMY

Tjahjono, H.K., Palupi, M. \& Dirgahayu, P. (2015). Career perception at the republic indonesian police organization impact of distributive fairness, procedural fairness and career satisfaction. International Journal of Administrative Science \& Organization, 22(2):130135

Tjahjono, H.K., Palupi, M. \& Dirgahayu, P. (2015). Peran pemediasian kepuasan karir pada pengaruh keadilan distributif dan keadilan prosedural karir pada komitmen afektif karyawan swasta di provinsi daerah istimewa yogyakarta. Akmenika, 12(1):563-573

Wahyudin, M dan Dewi, P., 2015, Pengaruh Motivasi Karyawan, PPKP, dan Persepsi Keadilan atas Kompensasi Terhadap Kepuasan Kerja Karyawan pada PT Bank Negara (Indonesia) tbk Kantor Cabang Surakarta. File download www.Roogle.com tanggal 22 April 2015

Wexley, K.N., dan Yukl G.A, 2005, Perilaku Organisasi dan Psikologi Personalia. Jakarta: Rineka Cipta. 